\title{
Accounting Data and the Balanced Scorecard - Goals and Indicators
}

\author{
Musinszki Zoltán \\ PhD, Faculty of Economics, University of Miskolc, Hungary \\ Süveges Gábor Béla \\ $\mathrm{PhD}$, Faculty of Economics, University of Miskolc, Hungary
}

\section{Abstract}

In their study, Relevance Lost: The Rise and Fall of Management Accounting, Johnson and Kaplan concluded that management accounting systems since the 1980s have failed to meet the new challenges of a changing environment. Among other things, because managerial accounting has been subordinated to the needs of financial accounting. Financial accounting cannot provide adequate information to management and does not support strategic decision making. The reason for this can be found in the operational logic of financial accounting. Financial accounting is past-oriented, it evaluates (economic) events in money, and thinks in the short term. Would all this mean that financial accounting data cannot be used to support long-term decisions? In our study, we point out the connection between financial accounting data assets and strategic decision support. Our research question focuses on how financial accounting data, including an invoice issued by a company, can be used in Balanced Scorecard perspectives. Based on the content of the Balanced Scorecard, we want to point out where and what kind of relationship can be observed between financial accounting data assets and the BSC. Through a case study, we will present the strategic goals as well as the indicators suitable for measuring the goals. These will be presented for all aspects of the Balanced Scorecard. ${ }^{1}$

Keywords: financial accouting, KPI, strategy, balanced scorecard

JEL Classification: M49

\footnotetext{
${ }^{1}$ Acknowledgment: This research was supported by the project nr. EFOP-3.6.2-16-2017-00007, titled Aspects on the development of intelligent, sustainable and inclusive society: social, technological, innovation networks in employment and digital economy. The project has been supported by the European Union, co-financed by the European Social Fund and the budget of Hungary.
} 


\section{Introduction}

\section{Literature Review}

\subsection{Balanced Scorecard}

In today's highly competitive environment, financial indicators alone cannot provide a direction for the future, they typically provide a picture of some of the actions of the past, so they are only retrospective indicators. Theoretical research and practical experience also confirm the need for both financial and non-financial indicators in corporate performance evaluation. A balance must be struck between them and they must be combined in a complex system of indicators. This is achieved by the Balanced Scorecard (BSC) indicator system. (Musinszki - Süveges, 2019)

The BSC is a balanced strategic evaluation system based on performance indicators.

- Balanced because:

- it seeks to balance the perspectives within the system,

- it takes into account both objective, easily quantifiable outcome indicators and subjective performance indicators that depend somewhat on individual judgment.

- strikes a balance between short-term and long-term goals.

- Strategic and based on performance indicators, because it translates strategic goals and initiatives into concrete metrics, as a result of which the strategy is implemented.

- Evaluation system: because the set target value is continuously compared with the actual performance, feedback can be implemented based on deviation analysis.

The BSC perspectives (finance, customers, internal processes, learning and growth) seek answers to four questions (or four groups of questions):

- What do the owners expect?

- How should the company be positioned towards investors?

- What needs to be achieved for the company to be financially successful according to the owners?

- What performance do customers expect?

- What do we need to do to satisfy customers?

- How to present ourselves to customers so that we can successfully implement our strategy?

- In which processes should outstanding performance be provided? 
- Which processes do we need to optimize to meet the expectations of our customers?

- In which processes do we need to deliver excellent performance to keep our customers and owners satisfied?

- How can the capacity for change and development be maintained in the future?

- How does the organization need to evolve to realize its vision?

- What do we need to do for organizational and individual learning and innovation, to be able to change?

Answers to these questions can be used to set goals, translate goals into indicators, and select tasks and actions to be performed. Each of these criteria is accompanied by a so-called scorecard, which includes

- the strategic goal,

- the indicators,

- the expected values of the indicators, and

- actions required for implementation. (Kaplan - Norton, 1992, 1996)

The four-element system provides a transparent structure and thus makes it possible to filter out actions and goals that deviate from the strategic direction, even at the operational level. By continuously examining the goals and actions formulated within each aspect, the four perspectives can be coordinated. (Kaplan - Norton, 2004)

By designing the BSC, managers need to align financial goals with the company's strategy. The financial goals are at the centre of the goals and indicators of the other three perspectives. Each of the indicators is part of a causal chain that is expressed in the improvement of financial performance. This, of course, is no accident, as financial performance arises as a result of operational performance. (Fenyves et al., 2018, Veresné, 2013) 


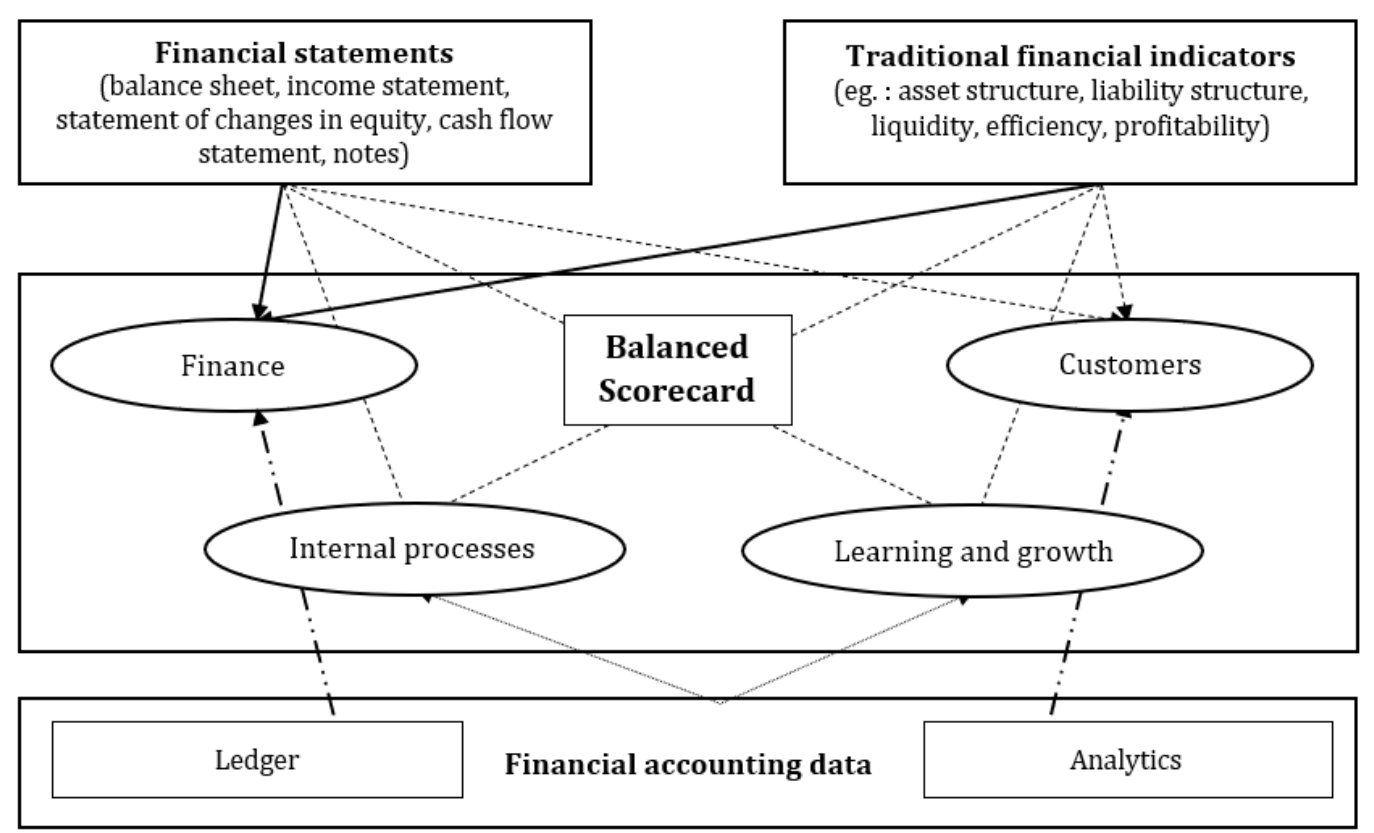

direct relationship

indirect relationship

Figure 1: Relationship between financial statements and Balanced Scorecard

Source: Own edition

\subsection{Integrating Financial Indicators into Strategic Decision Support Methods}

The limitations of financial statements partially affect synthetic and analytical records as well as the usefulness of the supporting basic documents. One one hand, as they are directed at past events, on the other hand, as a result of the accounting (and taxation) system. At the same time, the problem of the value limit and the business year can be solved. All of these come back when we look at the basic document of the invoice as a basic accounting and taxation document.

In order to harmonize the VAT rules applicable in the member states of the European Union, council directive 2006/112 / EC on the common system of value added tax lays down the general principles governing the issue of invoices. The directive sets out the rules for invoicing in a total of six sections. The definitions partly define the concept of "transmission or making available by electronic means" and then define in a separate section which documents are to be considered as invoices. Among other things, this is where the documents or messages in paper or electronic form that can be accepted as invoices are listed. After the sections on the issue of invoices and the 
content of invoices, the directive describes the electronic transmission of the invoice and then, among the simplification measures, highlights those aspects of invoicing for which member states have more or less room for manoeuvre, so they can deviate from the directive. This is followed by a description of the specific obligations of invoice preservation and the rules applicable to tax registration in the next chapter (Szente, 2019).

Invoices issued pursuant to Articles 220 and 221 of the Directive shall bear the following particulars:

- the date of issue of the invoice;

- a serial number consisting of one or more lines of numbers that uniquely identifies the invoice

- the value added tax identification number used by the taxable person to supply the goods or services;

- the value-added tax identification number of the customer in cases where he is the one liable to pay the tax,

- full name and address of the taxable person and the customer (customer);

- the quantity and nature of the products sold or the extent and nature of the service provided;

- the date of completion or completion of the supply of goods or services;

- the tax base per tax rate or tax exemption, the unit price excluding value added tax and any deductions, discounts or refunds if these are not included in the unit price;

- the value added tax rate to apply

- the amount of value added tax to pay

- any other indication that the supply of goods or services is subject to a taxfree or reverse taxation procedure, in the case of a tax exemption or when the tax liability is borne by the purchaser of the product or the recipient of the service;

- other data in case of sale of new means of transport, travel agencies, secondhand goods, works of art, collection pieces and antiques

- the value added tax identification number and the full name and address of the tax representative, in case a tax representative is liable to pay the tax (Council Directive 2006/112 / EC of 28 November 2006 on the common system of value added tax, Article 226) 
Simplification of the basic possibilities for implementation of Article 238 is possible, but also in these cases the number and the following:

- date of issue of the invoice;

- the name of the taxable person;

- a description of the products or services sold;

- the amount of value added tax due or the information needed to calculate it (Council Directive 2006/112 / EC of 28 November 2006 on the common system of value added tax, Article 238)

Under Article 238, simplification measures may be implemented, but in these cases, the invoice still must contain the following information:

- date of issue of the invoice;

- the name of the taxable person;

- an indication of the type of products sold or services provided;

the amount of value added tax due or the information needed to calculate it (Council Directive 2006/112 / EC of 28 November 2006 on the common system of value added tax, Article 238)

The basic rules of the obligation to issue invoices and receipts are not accidentally influenced by the directives on value added tax, "since the invoice is primarily a receipt for this type of tax. The basic purpose of the rules is to ensure that the invoice properly reflects the actual transactions that take place in reality. Of course, this does not mean that the bill is not relevant in other areas" (Barta, 2017, p.1), but it does determine the nature and possibilities of the use of the data content. That is why it is necessary to combine financial and accounting data with a complex system of indicators.

But how do financial statements and the Balanced Scorecard relate? Let's take a brief look at each point of view. Based on the content of the perspectives, we would like to point out where and what connection can be observed between the financial statements and the BSC.

The key question from a financial perspective is: How do owners determine a company's position? Indicators from a financial perspective indicate the extent to which the strategy and its implementation contribute to an organization's financial position, most often to its profitability. Financial goals are mainly related to profitability, return on assets or increase in sales revenue. Here are the classic financial indicators such as sales revenue, costs, profit, working capital. And all of these appear directly in income statements. However, sales revenue, cost and profit are only the starting points. Based on these, a multitude of indicators can be determined. Including but not limited to: 
- Sales Growth Rate,

- Operating Profit Margin,

- Incremental Fixed Capital Investment,

- Incremental Working Capital Investment,

- Earnings Before Depreciation, Interest and Taxes,

- Earnings Before Interest and Taxes,

- Return on Investment,

- Return on Assets,

- Return on Sales,

- Return on Equity.

A common feature of all indicators is that the data needed to calculate them can be found in the financial statements. (Tóth and Zéman, 2018)

The key question from a customer perspective is: How do customers judge an organization's performance? When developing a customer perspective, it is necessary to identify the customers and market segments where the organization wants to compete. Financial goals can only be met by an organization if it produces products or provides services that are valued by customers. We cannot satisfy the needs of all customers, so it is advisable to set target values for each segment. The customer aspect is therefore fundamentally focused on making the relationship with customers fruitful and lasting in the long run. Based on the recommendation of Kaplan and Norton (Kaplan and Norton 1992), indications of market share, product range, customer satisfaction, complaints, returns, profitability of customer groups, number of retained and new customers, etc. are included here. The financial statements (balance sheets) contain the customers and may contain the evaluation of the customers may (eg notes). The analytical records behind the financial statements show, among other things, the number of old and new customers and the profitability of customers/customer groups. At the same time, we do not get an answer to, for example, market share and customer satisfaction. So financial statements and traditional financial indicatiors appear in the customer perspective of the BSC, but they alone cannot fill the customer perspective with content.

The key question of the internal processes perspective: In what processes does an organization need to deliver outstanding performance? From this perspective, processes need to be identified where the organization needs to deliver outstanding performance in order to meet the objectives set out in the financial and customer perspective. Previous approaches have focused on existing processes rather than those that are relevant to the implementation of the strategy. Another novelty of Norton and Kaplan's approach is the integration of the innovation process into 
internal processes. Long-term success requires future orientation, the mapping of future consumer needs, and (new) products and services that can be used to meet the expected needs. (Kaplan and Norton 1992,1996) These include indicators on supply chain management, organizational innovation, and process regulation. Typical indicators of the internal processes point of view: product/service quality, efficiency, lead times. Financial accounting can only partially track organizational, for example production processes. Accounting is suitable for tracking resource usage (cost accounting). Partly suitable for monitoring quality processes (e.g. scrap, scrapping). However, these capabilities of the accounting system cover only the determination of a few indicators. Thus, financial accounting can typically only support the BSC in an indirect way.

The key question of the learning and growth perspective is: How to preserve the development and change capacity of the organization? The learning and growth perspective provides the background that ensures the success of the previous three perspectives. A short-term financial approach can easily result in the organization not paying enough attention to its employees, the skills of its employees, and its information systems. The organization can only achieve its strategic goals by investing in people (training), systems (information system) and procedures (information technology) and by encouraging its employees to act in accordance with the organizational goals. The three pillars of the perspective are therefore:

- skills of employees,

- information system skills,

- alignment of motivation, authorization, individual and organizational goals.

Measuring the abilities of employees and motivation are not classic accounting tasks. Financial accounting, like the previous point of view, can only support this point of view by relying on a database of analytical records. For example, the simplest, most common indicator of productivity is sales per employee. Or, to measure employee retention, the (key people) turnover rate is the most often quantified.

\section{Research Methodology and Results Balanced Scorecard and Accounting Data Assets - Case Study}

An additional possibility to use financial indicators is to use them not alone but in addition to and in combination with strategic decision support systems. Today, there are many strategic decision support methods, which can be grouped according to the following aspects: the purpose of use (situation analysis, setting strategic directions and goals, methods of strategy breakdown, strategy monitoring procedures), levels of analyzed and examined environment (micro, industry competition -, macroenvironment) the position of the examined environment in relation to the company, or the possibility of influence (tools for analyzing the external and internal 
environment) and the complexity of the methods (simple and comprehensive methods).

The special relationship between financial indicators and strategic decision support methods lies in the fact that financial indicators can not only complement the tools for measuring and analyzing the environment and strategy, but in many cases are essential elements for an accurate and comprehensive assessment of strategy and the corporate environment (excellent examples include tools for measuring and analyzing corporate life cycle, product life cycles, and industry trends, among others). (Ansoff 1957, Levitt 1965, Porter 1979, 1980, 2008)

Let's review the above-mentioned thoughts through a case study!

The company sells children's furniture and is present in the domestic market and neighbouring countries (Austria, Slovakia). It is among the market leaders in terms of sales in Hungary, it has entered the international market in Austria 5 years ago and in Slovakia 6 years ago. He has 30 years of manufacturing experience in Hungary. The centre is located in Győr, where there is also a warehouse and a showroom, and abroad there is a showroom connected to 2 warehouses. One in Vienna, another in Bratislava. Orders from customers can be placed in person at all three locations, and payment methods can be by credit card or cash. Another ordering method is possible through the website, it is in Hungarian, but customers can choose from 3 locations, so they can place their order in German or Slovak, which they can pick up or deliver from the appropriate centre, in case of online ordering the price of the ordered products must be paid in advance. Information about resellers is that the company expects a payment period of up to 60 days.

In order to track and plan for results, company management wants to create a scorecard that can track company performance. The goal for professionals is to help produce metrics that measure a company's performance.

\section{Financial point of view}

Target function: Within the company's total revenue ratio, the share of foreign revenue should increase by at least $10 \%$ compared to the previous year, increase the share of revenue to corporate customers in domestic revenue by $10 \%$ compared to individuals. Another expectation is that the company group should sell $15 \%$ more of the key product each year!

\section{Indicator:}

1. Value of an average order for an individual/company broken down by country on an annual basis

Average order value: Considering a business year, we consider the period from January 1 to December 31. Total order value / total number of orders. The report is prepared on a monthly basis, and the result can be filtered by 
country. (Multiple years could be compared in this way, allowing you to keep track of, eg. the average order value for the last 3 years in March.)

2. Distribution of revenues by country, broken down by year, showing separately the values of individuals and companies

The order counts for the country from which the delivery takes place! So, if you order from Győr to Slovakia, the place of sale is Hungary. (In this case, it would be useful to examine who are those who order from, eg. Slovakia, because Győr is closer to them, they get the product faster, and the same is the case in Austria. If there is a solution here, we can further increase revenue with the right business decision, this idea is not specifically related to the indicator -just a comment- could it be a problem with the employees or the foreign branch itself?)

3. Top10 Revenue from sales of key products / total revenue

Top10 Key Product: Most sold products. Here we examine products that we have been selling for at least 5 years.

\section{Customer perspective}

Target function: increase sales from top customers by at least $15 \%$. Increase sales of key products by top customers by $20 \%$ and increase the ratio of payments via credit card and bank transfer by 20\%. (TOP10 buyer: Companies that order in the highest value in their country within a year, those belong here who order for at least 20 million HUF in a year. (Individuals will not belong here because the purchase of 1-2 furniture in a year is typical there)

\section{Indicator:}

1. Top10 customer indicator

The ratio of Top10 customer purchases to total company value and total annual revenue, broken down by year and country.

2. Individual ratio

The ratio of the value of purchases made by all individuals to total sales. Annually broken down by country.

3. Top10 key product buyers indicator

The proportion of sales of top10 key products sold in a given year among customers by country. (it is worth examining the results of the last 5 years at most, due to entering a foreign market) 


\section{Internal processes point of view}

Target function: To increase sales of products launched in the last 3 years by $20 \%$.(New product: product introduced within 3 years.)

\section{Indicator:}

1. Sales indicator

The ratio of revenue from new products to total revenue. (by country, broken down by month)

2. Number of products sold indicator

How many pieces of the examined products have the company sold in the last 3 years. (by country, broken down by month)

3. Product defect indicator

The proportion of new products taken back from the customer because of some manufacturing defect compared to all new products sold. (packaging defect, damaged product, missing parts - broken down by country per month).

It shows how good the manufacturing technique is for the new products we produce. How do we want to grow if we produce it incorrectly? As a result, the value of other orders may fall, and the confidence of customers and buyers may decline.

\section{Learning and growth perspective}

Target function: To reduce the proportion of cancellation invoices issued by $20 \%$. Improve the error rates of correct invoices by $30 \%$.

\section{Indicator:}

1. Cancellation invoice indicator

What percentage of all invoices issued by billing clerks were cancelled. The report is prepared on a weekly, monthly, annual basis, and includes the name and ratio of the employee. The report is prepared by region.

\section{Top billing indicator}

In addition to the number of invoices issued by employees, the error rate is also indicated. (Assuming the billing program records the data of the creator as well.)

The report is prepared in daily, weekly, monthly, annual breakdown, it contains the name of the given employee, the number of issued pieces, and the error rate. The report is prepared by region. Employees are reported in descending order. The one who issued the most invoices during the given period will be listed above. 


\section{Conclusions}

As financial accounting cannot provide adequate information to management, it does not support strategic decision-making, so managers need complex systems that can be used to plan for the future using data based on the past. Our research question focused on how financial accounting data can be used to support long-term decisions. In our study, we pointed out the link between financial accounting data assets and strategic decision support and used the case study methodology to show the connections between financial accounting data assets and the BSC, and also provided examples of the Balanced Scorecard, strategic goals and indicators suitable for measuring the goals.

\section{Acknowledgment}

This research was supported by the project nr. EFOP-3.6.2-16-2017-00007, titled Aspects on the development of intelligent, sustainable and inclusive society: social, technological, innovation networks in employment and digital economy. The project has been supported by the European Union, co-financed by the European Social Fund and the budget of Hungary.

\section{References}

[1] Ansoff, I., 1957. Strategies for Diversification, Harvard Business Review, 5, pp. 113-124.

[2] Barta, B. 2017. Számla- és nyugtakibocsátási kötelezettség

[3] Fenyves, V., Bács, Z., Zéman, Z., Böcskei E. and Tarnóczi, T., 2018. The Role of the Notes to the financial statements in corporate decision-making, Corporate ownership and controls, 4 pp. 138-148.

[4] Kaplan, R. S. and Norton, P. D., 1992. The Balanced Scorecard - Measures that Drive Performance, Harvard Business Review, 1-2, pp. 71-79.

[5] Kaplan, R. S. and Norton, P. D., 1996. Using the Balanced Scorecard as a Strategic Management System, Harvard Business Review 1-2. pp. 75-85.

[6] Kaplan, R. S. and Norton, P. D., 2004. Strategy Maps Converting Intangible Assets into Tangible Outcomes. Harvard Business Review Press

[7] Levitt, T.,1965. Exploit the Product Life Cycle. Harvard Business Review 6. pp. 81-94.

[8] Musinszki, Z. and Süveges, G. B., 2019 Strategic Decision-Making Supported by Traditional Financial Indicators. Oradea Journal of Business and Economics IV. : 1. pp. 29-37.

[9] Porter, M., 1979. How competitivene forces shape strategy. Harvard Business Review, 2, pp. 137-145.

[10] Porter, M., 1990. The competitve advantage of nations; Harvard Business Review, 2, pp. 73-91.

[11] Porter, M., 2008. The five competitive forces that shape strategy; Harvard Business Review, 1, pp. 25-40. 
[12] Szente, M., 2019. A számlakiállítási kötelezettség. Adó szaklap, 2019/14. Általános forgalmi adó

[13] Tóth, A. and Zéman, Z., 2018. Stratégiai pénzügyi controlling és menedzsment. Budapest: Akadémia Kiadó.

[14] Veresné, S. M., 2013. A szervezeti kompetencia- és képességépítés néhány sajátossága. Controller Info, 11, pp. 21-30.

[15] Council Directive 2006/112 / EC of 28 November 2006 on the common system of value added tax, Article 226, 238 